\title{
The Introduction of the Otter Trawl
}

\section{Trevor John Kenchington}

Le chalut à panneaux, principal engin de pêche de fond commercial du 20e siècle, a vu le jour vers 1860 comme matériel de pêche récréative, probablement par la fusion de panneaux de chalut de surface ("otter boards») et de chaluts irlandais (« hammer trawls »). Il était utilisé par lesplaisanciers et les scientifiques, mais son acceptation par les pêcheurs commerciaux a dû attendre l'arrivée du chalutage à vapeur à partir de 1881, l'installation de panneaux de chalut sur les filets carrés des chaluts àperche vers 1890 et la promotion de cette combinaison auprès des funes enpair à partir de 1894. L'adoption du nouvel engin se fit alors très rapidement. Par contre, l'évolution du chalutage à panneaux vers un système efficace de récolte $d u$ poisson de fond s'est prolongée jusqu'aux années 1920. Parmi les avances nécessaires, notons les treuils à deux tambours, lesfortes potences de chalut et la conception améliorée des filets.

Throughout the twentieth century and onwards to the present, otter trawls have been the preeminent gears for the harvest of bottom fish, worldwide. ${ }^{1}$ Since the 1960s, trawls have been similarly important in midwater fisheries. Yet, commercial otter trawling only emerged in the 1890s. Its introduction, a largely British development, has been widely, though erroneously, credited to James Robert Scott of Granton, Edinburgh. Scott did make two important contributions but neither was the one usually ascribed to him. In reality, the development of the new gear into a practical, efficient means of fish harvesting was the collective work of many hands over seven decades, beginning around 1860.

1 I am indebted to David Sheppard, librarian at the Bedford Institute of Oceanography, for access to some rare works and to Dr. Poul Holm for Danish accounts of Nielsen's early experiments. Drs. Gareth Harding and Ellen Kenchington kindly provided valuable comments on earlier drafts, as did anonymous reviewers.

The Northern Mariner / Le marin du nord, XVIII, No. 4 (Autumn 2018), 327-46 
I here present that extended development, as an account of a watershed in global fisheries history, with major implications for marine environments, but also as a case-study in technological innovation.

\section{Precursors}

Otter trawls comprise one family within a broader class of nets drawn across the seabed, many varieties of which emerged down the centuries in small-scale, coastal fisheries. Most have been lost to knowledge but Duhamel du Monceau and Sañez Requart have left us detailed accounts of pre-nineteenth century French and Spanish fishing gears. ${ }^{2}$ Besides beach seines, they illustrated assorted nets drawn by boats, some being seines and others of bag-like shape. Each type of gear had the challenge of spreading the net's mouth both vertically and laterally. The former could be achieved with floats on the headrope and weights on the footrope, ${ }^{3}$ though rigid spreaders were often added. Lateral spread was easy when beach seining, the ends of the net being hauled from separated points, but was problematic at sea. du Monceau illustrated variants with poles lashed across the mouth of a net and other gears in which the warps were taken either to spars projecting widely from the fishing vessel or else to each of a pair of boats.

The fishermen of other nations appear to have employed similar nets but the Dutch and English also used beam trawls. ${ }^{4}$ In those, a wooden beam was held above the seabed by an iron trawl head at each end, the beam and heads together providing both vertical and lateral spread (Figure 1). The net's headrope was lashed to the beam while the long footrope dragged behind. Thus, fish herded towards the centre, or bosom, of that footrope were surrounded, with the seabed below and netting above, reducing opportunities for escape. Beam trawls proved both practical to handle and efficient for the capture of valuable flatfish.

Trawling was long limited to minor, coastal fisheries, meeting local demand. Rapid expansion began around 1750, linked to growing markets, improved roads (hence affordable rapid transport of fresh fish) and the adoption of smacks decked, gaff-rigged vessels of about twenty tons- in place of earlier inshore boats. By the 1830s, smacks from Brixham, Devon were trawling throughout the English Channel, the Irish Sea and along the North Sea coast of England.

Population growth, urbanization and industrialization were then creating a mass market for low-cost seafood, linked to landing ports through swift, efficient

2 H.-L. Duhamel du Monceau, Traité Général des Pesches (Premiere Partie) (Paris: Saillant, Nyon \& Desaint, 1769), pag.var.; A. Sañez Requart, Diccionario histórico de los artes de la pesca nacional (Madrid: Ibarra, 1791-95), pag.var.

3 Fisheries terminology is inconsistent. For clarity, I here use headrope and footrope throughout for the ropes to which the leading edges of seine- or trawl-net webbing are attached (ignoring any bolsh lines).

4 The development of English trawling has been outlined in many works but most usefully by R. Robinson, Trawling (Exeter: University of Exeter Press, 1996), which I follow in this section except where otherwise noted. 
Figure 1 : Beam trawl of 1880 s, seen from above, and three-quarter view of beam [from J.W. Collins, "The beam-trawl fishery of Great Britain, with notes on beam-trawling in other European countries, etc.," Bulletin of the U.S. Fisheries Commission VII (1887), Plates X and XI]
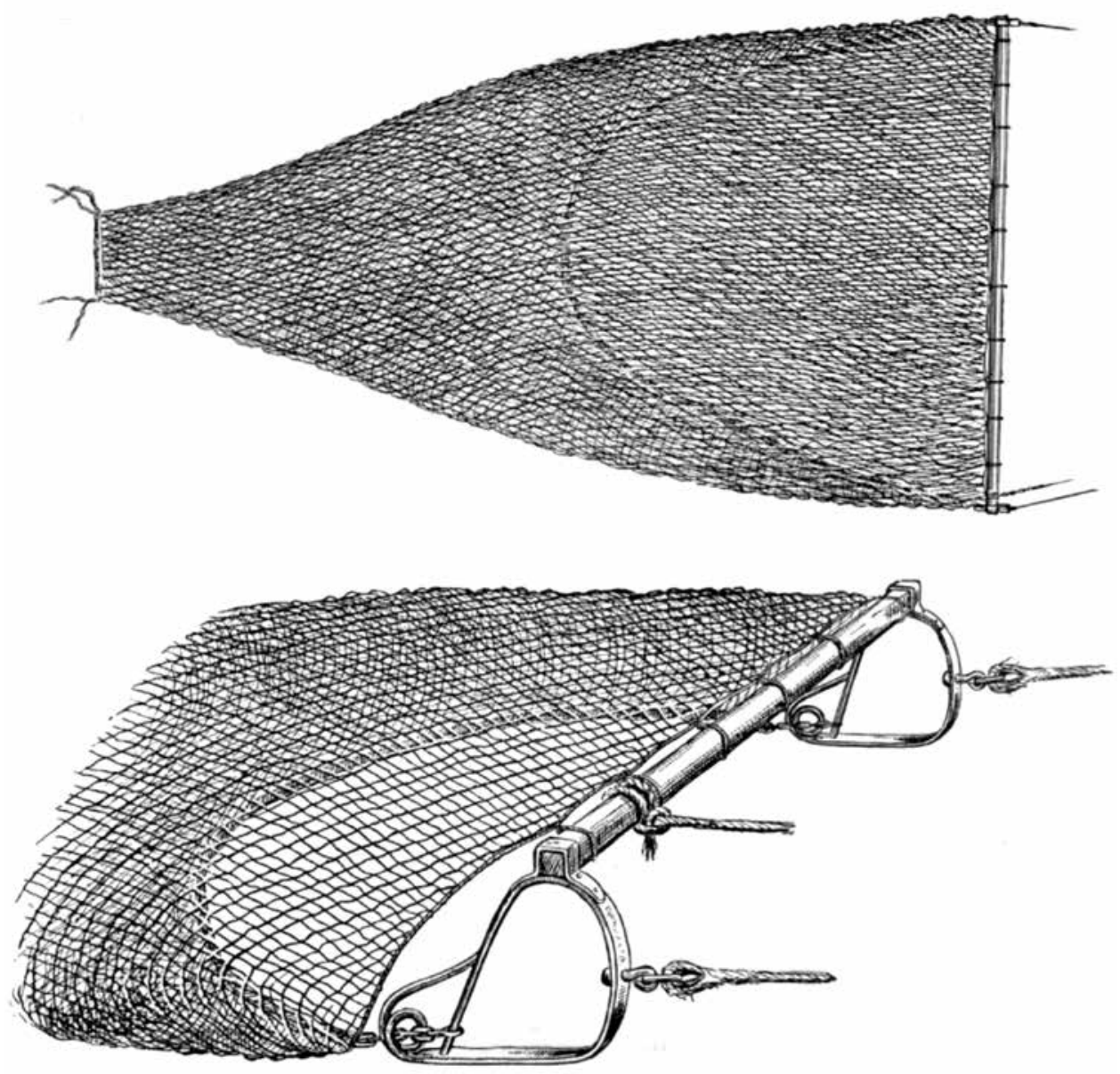

rail transport. That demand was met by further expansion of trawling onto the Dogger Bank, in the central North Sea, aided by icing of catches, the efficiencies of fleeting (in which smacks remained on the grounds for weeks, while fast cutters carried their catch to shore) and adoption of the Scottish smoked cure for haddock (Melanogrammus aeglefinus), which permitted exploitation of that abundant species..$^{5}$ By 1883, there were 3,000 deep-sea smacks in England and Wales, with

5 E.W.L. Holt, "An examination of the present state of the Grimsby trawl fishery, with especial reference to the destruction of immature fish," Journal of the Marine Biological Association 3:4 (March 1897), 365; Anon., "The history of trawling: Its rise and development from the earliest times to the present day," The Fish Trades Gazette and Poultry, Game \& Rabbit Trade Chronicle, 
a seagoing workforce of nearly 20,000 men and boys. ${ }^{6}$ The centre of the industry had moved north to the Humber ports: Grimsby and Hull.

Elsewhere, small-scale fishing with local gears continued but only French, Belgian and Dutch fishermen adopted the English techniques. Boulogne, the one major Continental trawling port, had a fleet of merely some sixty large smacks. ${ }^{7}$

Trawling technology changed little before 1880. Larger smacks were built and, from the mid-1860s, they were given two-masted rigs. Steel wire replaced hemp trawl warps from the 1870 s. Steam capstans were tried, though without much success until 1884. The trawls themselves were unaltered, except for being larger, with beams up to fifteen metres long. ${ }^{8}$

Meanwhile, there had been multiple, mostly unsuccessful, attempts at steam trawling. Efficient steam trawlers worked out of Arcachon, on the French coast near Bordeaux, from $1868^{9}$ but their employment in the North Sea awaited advances in marine engineering, allowing increased boiler pressures and improved fuel economy. Those were first applied in Zodiac of Grimsby, built in 1881. She was thirty metres overall, with a compound engine and a large steam trawl winch, ${ }^{10}$ allowing the wire warp to be conveniently stowed on the winch barrel. Her success led to construction of many similar trawlers, Grimsby having fifty steamers by 1890 and 425 before the end of the century, ${ }^{11}$ when Britain had nearly 1,250 in all. French fishermen were slow to adopt steam but had 103 trawlers in 1903, while a new German fleet emerged and grew to over 500 vessels by $1907 .{ }^{12}$ Until 1895 , however, they carried beam trawls unchanged from those of the smacks, save for a further size increase to seventeen metres. ${ }^{13}$ By then, otter trawls had existed for at least three decades, though who invented them and when remain obscure. Willam Carmichael McIntosh (or sometimes M'Intosh), Scotland's preeminent marine scientist, later claimed their use in the Firth of Forth in $1858 .{ }^{14}$ They were certainly known a decade later. ${ }^{15}$

19 March 1921, 61.

6 A.W. Ansell, “On trawling," International Fisheries Exhibition, (London: Clowes, 1883), 6.

7 H.-E. Sauvage, "La Pêche a Boulogne-Sur-Mer," Revue Maritime et Coloniale, 122, (1894), 213.

8 Anon., "The history of trawling," 65; E.J. March, Sailing Trawlers (London: Percival Marshall, 1953), 60-61, 94; Robinson, 67-68.

9 R. Pérotin, Le Chalutage à Vapeur à Arcachon (Bordeaux: Cadoret, 1911), 52-53.

10 J.W. Collins, "Suggestions for the employment of improved types of vessels in the market fisheries, with notes on British fishing steamers," Bulletin of the U.S. Fisheries Commission 8 , (1890), 183-186, provided a description of Zodiac, with general-arrangement drawings.

11 W. Garstang, "The impoverishment of the sea: a critical summary of the experimental and statistical evidence bearing upon the alleged depletion of the trawling grounds," Journal of the Marine Biological Association, 6:1 (July, 1900), 27.

12 Pérotin, 69-74.

13 Holt, 354.

14 W.C. M'Intosh, "Remarks on trawling," Journal of the Marine Biological Association 3:4 (March 1895), 318.

15 J.C. Wilcocks, The Sea-fisherman, $2^{\text {nd }}$ edn. (London: Longmans, Green, 1868), 241-244. It has been claimed that otter trawling was mentioned in the $18651^{\text {st }}$ edition. 


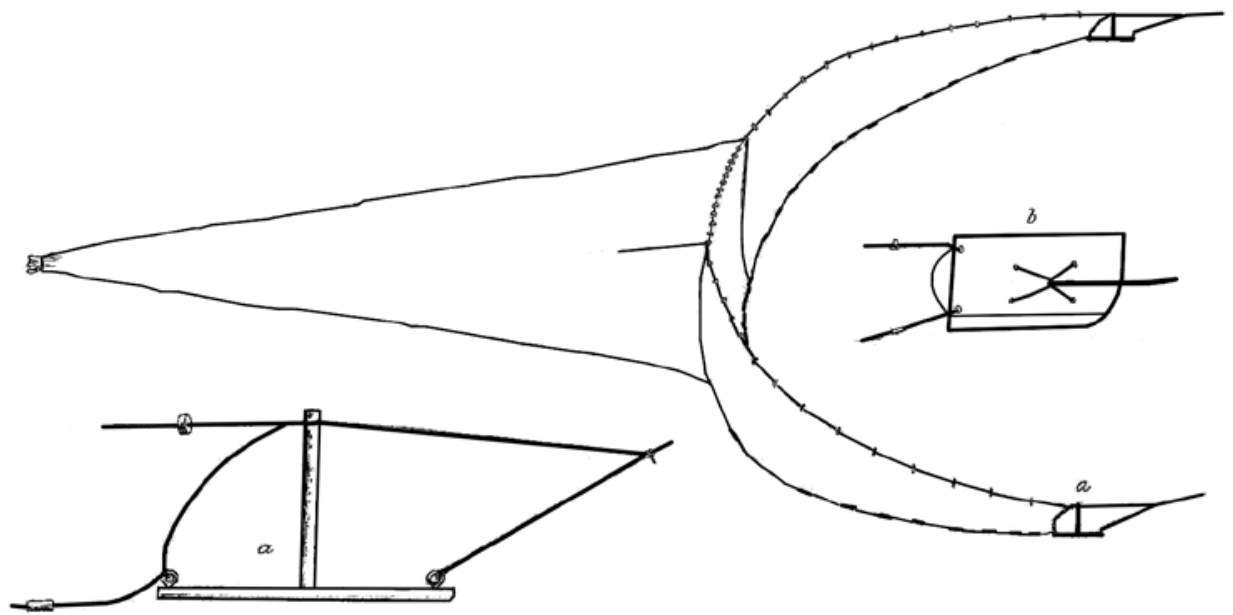

Figure 2 : Ring hammer trawl, with detail of hammer ("a") and Holdsworth's suggested alternative of an otter board ("b") [re-drawn after E.W.H. Holdsworth, Deep-Sea Fishing and Fishing Boats (London, 1874), Plate XV]

\section{Otter trawls for yachtsmen and naturalists}

The otter board itself was well established. The aquatic equivalent of a kite, it is a rigid body arranged at an angle to water flow so that it sheers away from a towing or anchor point. On the rivers and lakes of Ireland and Scotland, boards weighted to float at the surface were used to carry hooks away from the bank or a boat, though they were regarded as unsporting ${ }^{16}$ and were restricted in England under The Salmon Fishery Act, 1873. Seen amongst waves, such a board resembled the undulating swimming of an otter; hence the now-familiar term.

Weighting a pair of otter boards to run across the seabed and using them to spread the mouth of a net may have been independently invented several times but Edmund William Hunt Holdsworth, a contemporary writer and secretary to the 1860s Royal Commission on Sea Fisheries, regarded the idea as Irish, credited to a "Mr. Musgrave" and linked to the hammer trawls of Ring, a village on Dungarvan Bay. ${ }^{17}$ The latter were seines, with headropes and footropes of equal length, such that their wings rose vertically from the seabed (Figure 2). They were towed across the bottom with lateral spread achieved by leading the warps to long poles extending abeam of a boat, in a manner familiar to du Monceau a century before. The Ring fishermen achieved vertical spread of the wings of their nets by means of a pole set in an iron shoe that ran on the seabed, the combination being termed a hammer.

16 Wilcocks, 218-219; J. Bickerdyke, Sea Fishing, (London: Longmans, Green, 1895), 303;

F.M. Davis, "An account of the fishing gear of England and Wales," $4^{\text {th }}$ edn. Fishery Investigations, Ser.II 21:8 (September 1958), 61.

17 E.W.H. Holdsworth, Deep-Sea Fishing and Fishing Boats, (London: Stanford, 1874), 372. 
The only Musgraves in Ireland prominent enough to be recognized by Holdsworth's readers were the baroneted Musgrave family of Tourin House, County Waterford, ${ }^{18}$ which stands less than twenty kilometres from Ring. There is no reasonable doubt that the sporting Musgrave gentlemen knew both hammer trawls and otter boards, while simply replacing the hammers of a Ring trawl with weighted boards converted the gear into an otter trawl.

In 1868, James C. Wilcocks, a prolific writer on fisheries matters, presented otter trawls as suitable for amateurs, being easy to stow and avoiding the ugly addition of a trawl beam to a yacht's rail. ${ }^{19}$ Six years later, Holdsworth claimed that "The otter-trawl is much used on board yachts, ${ }^{, 20}$ though its series production was only beginning. That was led by Hearder's of Plymouth, Devon, a manufacturer and purveyor of sport-fishing tackle ${ }^{21}$ who claimed to have invented the otter trawl, ${ }^{22}$ though they merely promoted it.

The family business was established in $1770^{23}$ and by 1823 Jonathan Hearder was listed as a "gunsmith, fishing tackle, umbrella maker, \&c." 24 Jonathan Nash Hearder, son of the elder Jonathan, developed an early interest in the sciences, delivering his first lectures at seventeen. He was blinded soon after but continued his research, becoming a noted authority on electrical phenomena. ${ }^{25}$ On the death of his father, Jonathan Nash added the family's commercial activities to his scientific work, continuing both until his own death in 1876 . He may, however, have handed the tackle business to his younger son, William Sleep Hearder, some years before; Jonathan Nash was enumerated in 1871 as a "Medical Galvanist," whereas William was recorded as a "Fishing Tackle \& Umbrella Maker."26

Amongst his lectures before the Plymouth Institution, in January 1870 Jonathan

18 C. Mosley, ed. Burke's Peerage, Baronetage \& Knightage, 107th edn. II (Wilmington: Burke's, 2003), 2843.

19 Wilcocks, $2^{\text {nd }}$ edn., 241-244.

20 Holdsworth, 53.

21 J.J. Manley, Notes on Fish and Fishing, (London: Sampson Low, Marston, Searle \& Rivington, 1877), 106, listed "Messrs Hearder's establishment" second amongst the fishing tackle manufacturers in Britain.

22 An advertisement amongst the end matter of Wilcocks, The Sea-fisherman, $4^{\text {th }}$ edn. (London: Longmans, Green, 1884) proclaimed Hearder's as "Inventors of the celebrated otter trawls which have received that greatest amount of praise and flattery, viz., imitation." That was brazen, considering that the $2^{\text {nd }}$ edition of the same book had described the gear before Hearder's produced their first example.

23 A date claimed in an advertisement amongst the end matter of Wilcocks, $2^{\text {nd }}$ edn.

24 Anon., The Tourist's Companion; being a guide to the towns of Devonport, Plymouth, Stonehouse, Stoke, Morice-Town, and their vicinities, (London: Longman, Hurst, Rees, Orrme \& Brown, 1823), 94.

25 R. Oxland, "Dr. Jonathan Hearder," Annual Report and Transactions of the Plymouth Institution 6:1 (April 1877), 150-153; E. Cavicchi, "Blind experimenting in a sighted world: The electrical innovations of Jonathan Nash Hearder," Proceedings of the Plymouth Athenaeum 10 (2007), 39-48.

26 The National Archives, London, UK (TNA), RG10/2119, Folio 111, 30, Census Returns of England and Wales, 1871. 
Nash Hearder delivered one on "Degeneration of Our Deep Sea Fisheries." He pointed to indications of resource depletion and, in a vitriolic assault, blamed commercial netting, particularly fine-mesh shrimp nets, "ruthless, ravaging trawls" and ground seines that "scrape our bays and estuaries with impunity."27 Looking across the Tamar from Plymouth, the nets that so offended Hearder presumably included the Saltash tuck seine - a gear "structurally, the same as" a hammer trawl and yet functionally akin to a beach seine. ${ }^{28}$ Personal aversion to bottom-fishing nets notwithstanding, in pursuing an opportunity likely aided by Johnathan Nash's scientific connexions, the family won an order for beam trawls and trammels for the 1872-6 cruise of HMS Challenger, ${ }^{29}$ the voyage that began the science of oceanography. Soon after, Hearder's developed their otter trawl, which they advertised before $1875 .^{30}$ In essence, it was a small Saltash tuck net, fitted with otter boards for lateral spread (Figure 3). Hearder's supplied such trawls, along with other sampling gear, for the 1876-8 Norwegian North-Atlantic Expedition, ${ }^{31}$ though their intended market seems to have been amateur enthusiasts.

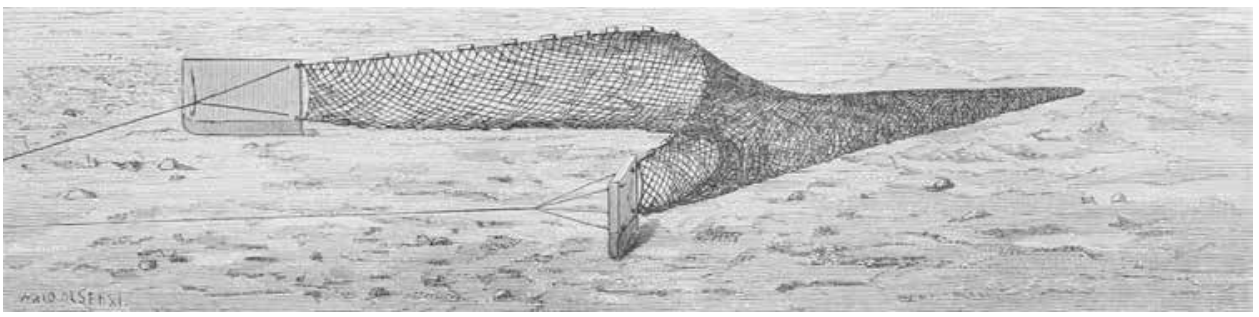

Figure 3 : Hearder's otter trawl of 1876 [from C.F. Wille, "The apparatus, and how used," The Norwegian North-Atlantic Expedition 1876-1878, Historical Account (Christiania, 1882), Figure 18]

Hearder's trawls were advertised in sizes from five metres (presumably headrope length), which sold for $£ 6$, up to twenty-seven metre nets, costing $£ 22$ and suited for vessels of 80 to $150 \mathrm{t}$ - the size of commercial smacks. The gear was worked on a single warp, like a beam trawl, with a bridle (or span) leading to the otter boards. Each of the latter had a "belly-band like that of a kite" for attachment of the bridle, ${ }^{32}$

27 J.N. Hearder, "Degeneration of our deep sea fisheries," Annual Report and Transactions of the Plymouth Institution 4:1 (1870), 43-48.

28 Saltash tuck seines were described by P.H.T. Hartley, "The Saltash tuck-net fishery and the ecology of some estuarine fishes," Journal of the Marine Biological Association 24:1 (January 1940), 1-68. Davis, 61,provided the comparison with trawls.

29 T.H. Tizard, H.N. Moseley, J.Y. Buchanan and J. Murray, "Narrative of the cruise of H.M.S. Challenger with a general account of the scientific results of the expedition," Report on the Scientific Results of the Voyage of H.M.S. Challenger I (London: HMSO, 1885), 10.

30 The $7^{\text {th }}$ edition of the company's tackle catalogue, J.N. Hearder \& Son, Guide to Sea Fishing and the Rivers of South Devon, (Plymouth: Hearder, 1875), 3, noted that otter trawls had been introduced in the $6^{\text {th }}$ edition. The publication date of the latter is unsure, though one source claims 1873.

31 C.F. Wille, "The apparatus, and how used," The Norwegian North-Atlantic Expedition 18761878, Historical Account (Christiania: Grøndahl, 1882), 37.

32 J.N. Hearder \& Son, 35-36. 
though contemporary illustrations ${ }^{33}$ show the four-legged connexion anticipated by Wilcocks and Holdsworth. ${ }^{34}$ Hearder's trawls, supplied as complete units ready for use, were intended for shallow water, though additional lead weights could be added to the boards, or chain to the bridles, when fishing deeper than twenty-five metres. Otter trawls could be worked from a smaller boat than a beam trawl of equivalent size and were claimed as easier to handle once hauled back to the rail..$^{35}$

Hearder's did not have the market to themselves. There were later claims that three net lofts in Bridport, Dorset (then, as now, a centre for net and twine manufacture) had built otter trawls, Herbert E. Hounsell Ltd. beginning in 1874, W. Hounsell \& Co. from 1880 and Joseph Gundry \& Co. subsequently. ${ }^{36}$

How much acceptance those trawls had amongst amateur fishermen is unsure, though there was some. The 1883 International Fisheries Exhibition heard a presentation on the development of the trawl fisheries by A.W. Ansell, in a session chaired by the Earl of Ducie. Afterwards, the chairman was lauded by Thomas Huxley, who described the earl as "an experienced and practical trawler." Ducie modestly declared that "it was only in an amateur way, as a yachtsman" that he trawled, with "an otter trawl, which could only be used in shallow water, and could never be spoken of in the same breath with a beam trawl. It was a very easy and very cleanly instrument, but only fit for amateurs." 37

For their part, the smacksmen had several reasons for not adopting the new gear. It was too complex to handle at night or in bad weather, while the light otter boards would not stay on the seabed unless surface conditions were calm. ${ }^{38}$ Weighting was critical; too light and nothing would be caught, too heavy and the gear would dig into the seabed..$^{39}$ Moreover, to maintain stability, otter boards needed steady warp tension, difficult to achieve under sail, while failures necessitated haulingback and re-setting at a serious cost in time. Finally, the derivation of otter trawls from seines, with headropes vertically above their footropes, enabled escape of those roundfish which respond to nets by rising off the bottom. ${ }^{40}$ The latter is a characteristic behaviour of haddock ${ }^{41}$ which were then important to the trawling industry.

33 Wille, 37; Bickerdyke, 303.

34 Wilcocks, $2^{\text {nd }}$ edn., 242; Holdsworth, 371.

35 J.N. Hearder \& Son, 35, 113-114.

36 Anon., "Scott v. Hamling and Co., Ld." and "Scott v. The Hull Steam Fishing and Ice

Company Ld.," Reports of Patent, Design and Trade Mark Cases, 14:6, 24 February 1897, 125.

Herbert E. Housell advertised otter trawls amongst the end matter of Wilcocks, $4^{\text {th }}$ edn. (1884).

37 Ansell, 28-29.

38 Holdsworth, 372.

39 Wilcocks, $2^{\text {nd }}$ edn., 243-244.

40 Bickerdyke, 307.

41 L.A. Krag, R. Holst, N. Madsen, K. Hansen and R.P. Frandsen, "Selective haddock (Melanogrammus aeglefinus) trawling: avoiding cod (Gadus morhua) bycatch," Fisheries Research 101:1-2 (January 2010), 20-26. 


\section{Introduction to the commercial fleet}

Despite those disadvantages, otter trawls were tried in commercial fishing. In 1878, the Commissioners for Sea Fisheries heard of their use in the bays of Cornwall and Devon. ${ }^{42}$ Meanwhile, the British economy was in prolonged recession. Demand for fish remained high, as consumers sought cheaper foods, while coal prices fell and a shipping slump left older paddle tugs idle. Some tugs, which were limited to coastal grounds, were fitted with trawls from 1877 and found fish on patches of bottom too small to work under sail. ${ }^{43}$ Most used beam trawls despite their paddle boxes restricting the beams, while steam offered steady warp tension. At least one skipper responded by trying otter trawling. The paddle tug Triumph carried the gear by $1882 .{ }^{44}$

The advent of Zodiac opened the possibility of otter trawling away from the coast. From 1887, Captain Dyer conducted trials aboard Irrawaddy, the first purpose-built steam trawler out of Hull, with her owner, George Beeching. Around 1890, they took out a patent with one Thurlow and in 1894 combined iron otter boards with the form of net used in beam trawling - promising the fish-trapping potential of a headrope shorter than the footrope. That became known as a square net, in contradistinction to the yachtsmen's trawls. However, Irrawaddy's trawl was worked on a single warp, like Hearder's, and proved unsuccessful. ${ }^{45}$

In 1887, Carl August Nielsen, born in Denmark but apprenticed to a Hull smack owner in $1867,{ }^{46}$ moved his own smack, Peter, to Esbjerg. There local fishermen used the skovlvaad - a seine that, alone among vernacular gears, was spread laterally by crude otter boards called skovle. Nielsen experimented with such "shovels" on his traw $1{ }^{47} \mathrm{He}$ was not alone. Frederikshavn fishermen then worked seasonally from Fanø, off Esbjerg. By 1888, on days with fresh breezes, some spread the mouths of their plaice seines with skovle, ${ }^{48}$ though whether they inspired Nielsen or were inspired by him is unknown.

Nielsen soon joined Anton Jacobæus Sølling in introducing steam trawling to Denmark, with Dania. In 1890, their initiative grew into the Dansk Damp Trawling Aktieselskab, which purchased a second trawler, Hafnia, and placed Nielsen in

42 F. Buckland and S. Walpole, Sea Fisheries of England and Wales. Appendix I: Evidence (London: HMSO, 1879), 6, 8.

43 Robinson, 85-87.

44 March, 42, plate 5.

45 J. Spillman, "Die Grundschleppnetze der Fischdampfer: das alte Baumnetz und das neue Scherbretternetz," Mittheilungen Deutscher Seefischerei Vereins 12:8 (August: 1896), 153; Anon., "Scott v. Hamling," 130, 132. Spillman dated the first otter trawling to 1885 but Irrawaddy did not run trials until late that year (Robinson, 92). Anon. ("Scott v. Hamling," 125) reported evidence that Beeching's initiative was in 1887.

46 TNA, BT 150, Piece 35, " Registry of Shipping and Seamen: Index of Apprentices."

47 A. Nielsen, Esbjerg Fiskeriforening 1892-1942. (Esbjerg: Esbjerg Fiskeriforening, 1942), 25-26.

48 Anon., "Bericht über eine Bereisung der Hauptfischereiorte an der Küste Jütlands," Mittheilungen Deutscher Seefischerei Vereins 4:11-12 (November-December 1888), 153. 


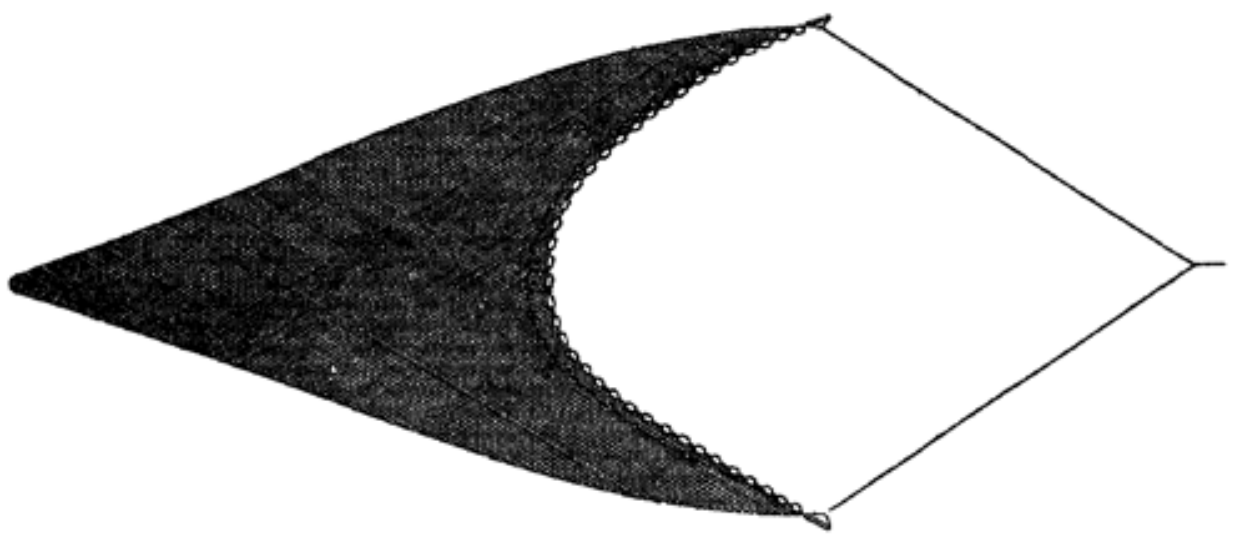

Figure 4 : Nielsen's 1895 otter trawl [from UK patent 189421638, downloaded from http://worldwide. espacenet.com]

command. His ship was lost at Iceland in $1893^{49}$ but, until then, he continued development of otter gear. ${ }^{50}$ The result was the first efficient commercial otter trawl but it was fly-backed, with its headrope as deeply curved as the footrope (Figure 4) - perhaps effective enough for flatfish, but ill-suited to haddocking. The bridles were attached to the otter boards through chain or wire slings, equivalent to belly bands, while the headrope was fitted with floats. ${ }^{51}$ In effect, Nielsen achieved a commercialized version of Hearder's trawl, though from a different root.

Meanwhile, James Robert Scott had also considered commercial otter trawls. Born in Edinburgh in 1866, by 1891 he was a marine engineer draughtsman in Glasgow. ${ }^{52}$ His father became manager of the General Steam Fishing Company, of Granton, ${ }^{53}$ which had introduced steam trawling to Scotland in the $1880 \mathrm{~s} .{ }^{54}$ During subsequent litigation, Scott "gave evidence that he directed his attention to the question of the fishing industry" around 1885, while he was in his teens. It is unclear when that interest merged with his engineering training and his father's trawling concerns but Scott surmised that fish were avoiding the trawl beams. He

49 P. Holm, "Technology transfer and social setting. The experience of Danish steam trawlers in the North Sea and off Iceland, 1879-1903," in P. Holm, O. Janzen, and J. Thór, eds., Northern Seas Yearbook 1996, (Esbjerg: Fiskeri- og Søfartsmuseets Forlag, 1996), 116-118, 127.

50 Anon., "Scott v. Hamling," 131.

51 UK Patent 189421638, "Improvements in Trawling Nets."

52 National Records of Scotland, Edinburgh, UK, Statutory Registers, Births 685/2 788; NRS Census 644/9 42/2.

53 J.T. Cunningham, "The adoption of the otter trawl in steam trawling," Journal of the Marine Biological Association 4:2 (May 1896), 114 identified James Robert Scott as the son of James Scott, manager of General Steam.

54 W.C. McIntosh, "Professor McIntosh's Report," Report of the Commissioners appointed to inquire and report upon [...] the use of the trawl net and beam trawl. (London: Eyre \& Spottiswoode, 1885), 353. 


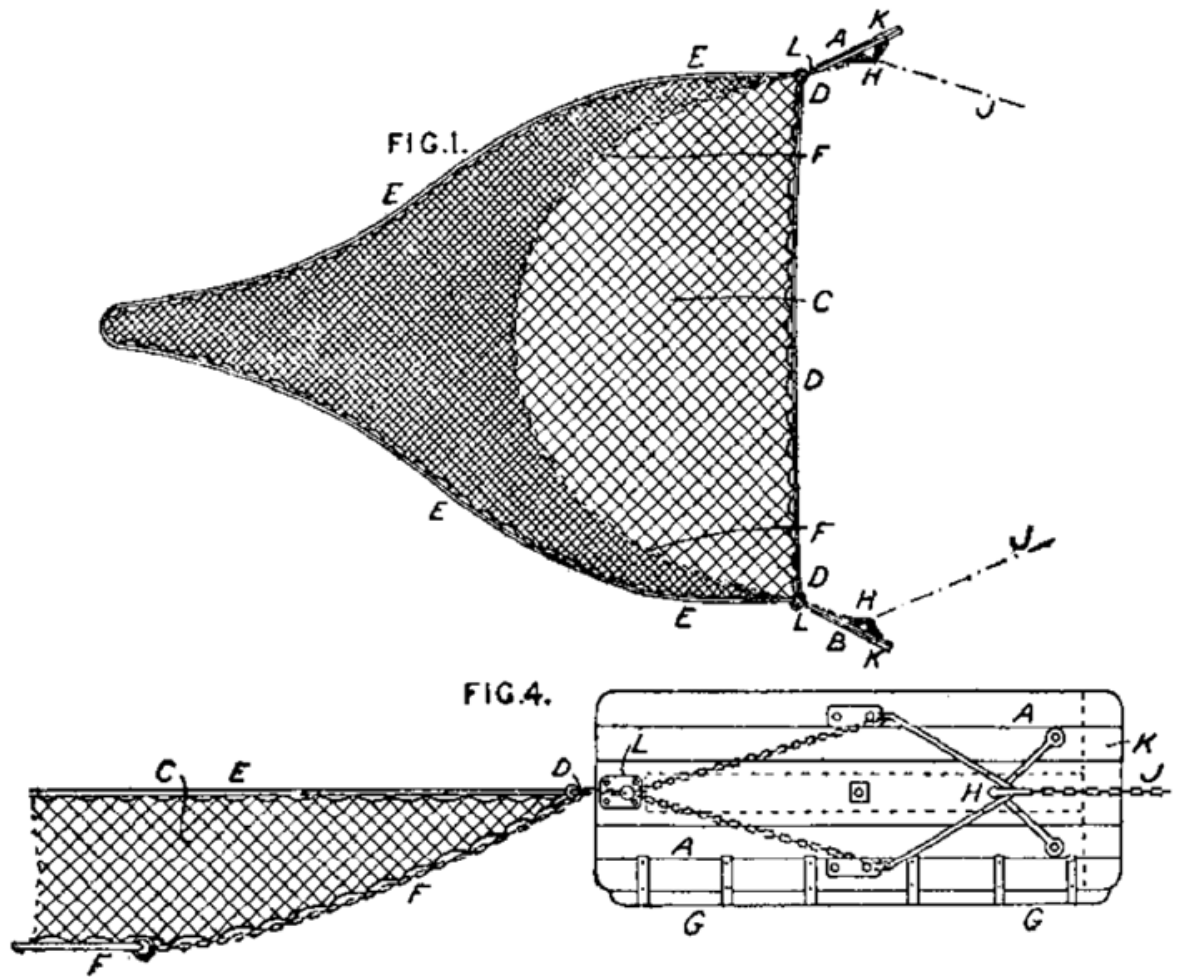

Figure 5 : Scott's 1894 patent otter board and its supposed use with a square net [from Anon., "Scott v. Hamling and Co., Ld.," Reports of Patent, Design and Trade Mark Cases XIV No. 6, 24 February 1897, p. 124]

had read of otter trawls and experimented with one in shallow water, replacing the otter boards' belly bands with a rigid towing point and modifying the net to a beam trawl's square form. ${ }^{55}$ By 1893 , Scott had boards suited for full-size square nets, which he tested aboard Athole, owned by General Steam. ${ }^{56}$ Scott applied for a patent in 1894 (UK patent 189403187: Figure 5) and his boards entered commercial service that June on nine of his father's trawlers, ${ }^{57}$ with twenty other licences taken up in England. ${ }^{58}$

Despite the title of his patent, "Improvements applicable to trawl nets," Scott neither designed a new net nor claimed to. His principal insight (also pursued by Beeching) was to use otter boards with square nets, releasing the gear from the constraint of practical beam length, while retaining the long footrope and its

55 Anon., "Scott v. Hamling," 128-129.

56 M'Intosh, "Remarks on trawling," 318.

57 Anon., Thirteenth Annual Report of the Fishery Board for Scotland. Part I. - General Report: Appendix N. Reports from the different Fishery Districts (Edinburgh: HMSO, 1895), 143; Cunningham, 117. The text of Scott's patent, along with its key illustrations, were published in Anon., "Scott v. Hamling," 123-125.

58 Anon., "Scott v. Hamling," 129. 
trapping action..$^{59}$ In a vain attempt to stretch the headrope straight (which would require an infinite spreading force, fighting the drag of the water), he used huge otter boards (3.7 $\mathrm{m}$ long and $1.5 \mathrm{~m}$ high). To facilitate raising them from the water, at the end of a haul, Scott placed "oblong wooden frames" (swiftly dubbed "gallows" by the fishermen) on deck, forward and aft, ${ }^{60}$ to which the boards were hoisted. For practical handling, in all weathers and at night, he worked his net with paired warps, rather than a single warp and bridle. ${ }^{61}$ Although unrecognized at the time, that was the key advance, bringing the success that had eluded others - a point taken up below.

Scott did not, however, patent any of those innovations but only his new otter board design. He linked each warp to its board by means of a rigid bracket, formed of iron bars, which set the angle to the water flow more firmly than slings or belly bands could - an alternative that Hearder's had tried but discarded. The bracket made the boards more stable when shooting away in bad weather, as well as helping them right themselves if they fell flat on the seabed, but made the boards harder to handle when hauled to the rail. Scott also attached both headrope and footrope to a single swivel on the trailing edge of the board, rather than separately to the upper and lower corners. ${ }^{62}$ That idea did not find lasting favour but Scott's brackets were a first step towards a form used through the decades. They certainly had advantages but, as the judge was to declare when Scott sought to defend his patent in court: "I do not think the discovery or invention of the Plaintiff can be considered a great one." ${ }^{63}$ It was far less than the invention of the otter trawl or its commercial application.

Scott's greater contribution was in arranging demonstrations of his gear in each trawling port, promoting the sale of licences for his patent otter boards. He went so far as chartering three trawlers for the purpose. ${ }^{64}$ Annual licences and a pair of boards were offered for $£ 100$ per trawler, later reduced to $£ 25$, for which Scott provided only a set of brackets to be attached to the licensee's own boards. ${ }^{65}$

Perhaps spurred by Scott's activity, in November 1894 Nielsen applied for his own patent, which was granted the following July (UK patent 189421638). He had seen one steamer fitted with his trawl in March 1894 and himself made a trip aboard Ceres the following January, taking one of his trawls. Emerald was given one the next month and licences were granted from May $1895 .^{66}$

59 Anon., "Scott v. Hamling," 127-129.

60 Cunningham, 114-116. Given the large size of Scott's otter boards, his frames rose man-high above the bulwarks. With the almost-piratical self-image popular amongst trawlermen, gallows was apposite.

61 Cunningham, 114-116.

62 Anon., "Scott v. Hamling," 123-125.

63 Anon., "Scott v. Hamling," 139.

64 Cunningham, 117; H.M. Kyle, "Fishing nets, with special reference to the otter trawl," Journal of the Marine Biological Association 6:4 (December 1903), 571.

65 Anon., "Scott v. Hamling," 127, 129.

66 Anon., "Scott v. Hamling," 134; A.H. Rasmussen, Fisken kender ingen granser. (Esbjerg: 
Scott's marketing effort reached Hull that summer. One of the first trawlers to try his gear was Madras of the Red Cross Fleet. She carried her otter trawl out to her sisters, working on the Dogger Bank, and did so well that each Red Cross vessel was converted to otter gear when she next went in for coal, even at the cost of a week or two of lost fishing. ${ }^{67}$ Almost all trawlers out of Hull and Grimsby were converted by late $1896 .{ }^{68}$ Joseph Thomas Cunningham, of the Marine Biological Association, visited Hull during the hectic first summer and observed a "remarkable revolution." Nets with headropes as long as $28.5 \mathrm{~m}$ were tried, as were various arrangements for handling them. The excitement was driven by an increase in catch rates which Cunningham estimated at 50 percent though it was really an increase in efficiency for roundfish, primarily cod (Gadus morhua) and haddock, particularly when fishing in daylight. ${ }^{69}$

Although they avidly adopted paired-warp otter trawling, most Hull and Grimsby trawler owners did not opt for Scott's large boards, with their rigid brackets. Their high drag increased coal consumption, while the boards were awkward and dangerous when the trawl was hauled back - and did not always successfully open the nets when fishing. By autumn 1896, only twenty Hull trawlers and three in Grimsby (plus twenty-four elsewhere) paid for Scott's licences. The others used smaller boards (about 2 by $1.2 \mathrm{~m}$ ) fitted with slings, initially of wire but later chain ${ }^{70}$ which they had learnt to handle, despite the inherent instabilities. During 1896-7, Hewett's of Barking, then a leading trawling company, prepared detailed records of contemporary otter boards. Designs varied widely but all in Hull and Grimsby had chain slings and only one had Scott's dimensions. ${ }^{71}$ Thus equipped, the trawlermen considered themselves to be using Nielsen's traw $1,{ }^{72}$ though how many used Nielsen's fly-backed net, versus putting otter boards with slings onto a square net, is unknown. ${ }^{73}$

In October 1895, Scott met the challenges to his patent by suing Hamling and Company Ltd. and The Hull Steam Fishing and Ice Company Ltd. It did him little good. The court upheld his rights only where otter-board brackets were concerned. Setting a seal on Scott's claims, one lawyer declared that "Nielson [sic], using the otter net, is simply running away from the Plaintiff; four boats out of every five

\footnotetext{
Esbjerg Fiskeriforening, 1992), 48-49.

67 Garstang, 52.

68 Anon., "Scott v. Hamling," 130.

69 Cunningham, 114-118.

70 Cunningham, 117-118; Anon., "Scott v. Hamling," 125-135.

71 Records of otter boards appear to have been collected as part of a detailed study by Hewett's staff. They were prepared in a ledger (now in Essex Record Office, catalogue D/F 13/9) entitled “Otters Gorleston from Nov 1896 - ," no concluding date having been added. A few of Hewett's boards for their own vessels had rigid brackets but ones quite different from Scott's.

72 Anon., "Scott v. Hamling," 134-135.

73 The nets used in Aberdeen soon after the turn of the century had headropes between 27 and an extraordinary 42.5 m. See: T.W. Fulton, "North Sea investigations. II," in Twentieth Annual Report of the Fishery Board for Scotland, Part III - Scientific Investigations (Edinburgh: HMSO, 1902), 120. The latter would be more understandable if it was a fly-backed net.
} 


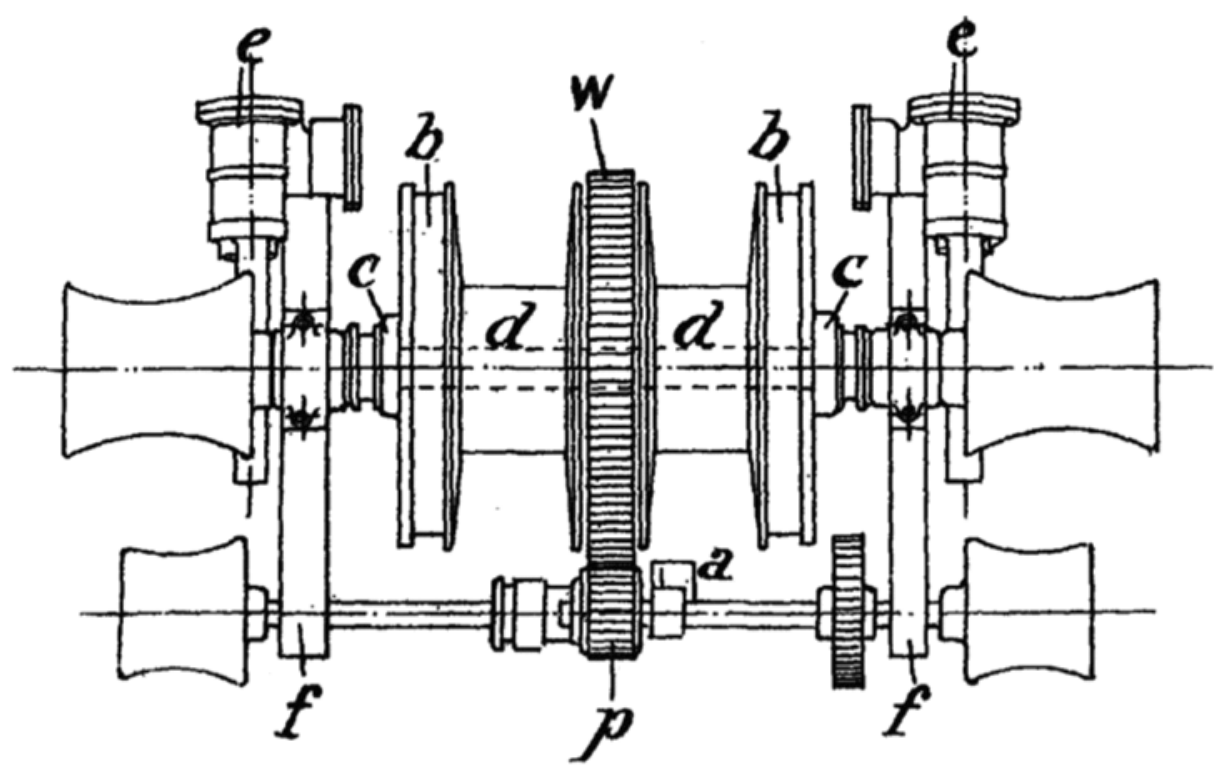

Figure 6 : One of Alward's 1895 trawl winch designs (barrels for warps marked "d") [from UK patent 189515209, downloaded from http://worldwide.espacenet.com]

use the chain slings. Therefore it is not fair to give Scott any credit for bringing in the otters." 74

\section{Refining the gear}

Although an improvement over beam trawls, the otter trawls of 1895 and the associated gear were seriously deficient. There were many on-board details affecting the efficiency, speed and safety with which the catch was got aboard and the trawl re-set, all needing refinement. Most seriously, although the new gear used paired warps, Cunningham did not mention modification of trawl winches. ${ }^{75}$ It seems that both warps were on the same winch barrel, preventing adjustment of relative lengths out to starboard and port, while causing much aggravation. Efficiency demanded a double-barrel winch, with clutches and brakes allowing the warps to be veered or hauled together or individually, as needed. The key patent (UK patent 189515209) was granted to George Lowe Alward, of Grimsby, in 1896 (Figure 6). Born in 1842, the son of a Brixham smacksman, he was a Grimsby alderman, fleet owner and leader of the trawling industry in the world's thengreatest fishing port. ${ }^{76}$ His winches still required dangerous work with handspikes, until mechanical spooling gear was added by Charles Denton Holmes, of Hull, in 1896 (UK patent 189629777).

74 Anon., "Scott v. Hamling," 138.

75 Cunningham, 114-121.

76 R. Robinson, “Alward, George Lowe," Oxford Dictionary of National Biography, https://doi. org/10.1093/ref:odnb/109604. 
A steam beam trawler used her winch to veer and haul the single warp but, once the trawl was down, tension was transferred to a strong point on board through a stopper, as in the smacks. In the 1890s, the stoppers were wire, labouriously fastened to the trawl warp with spunyarn that would break if the gear came fast on a seabed obstruction. ${ }^{77}$ By 1895 , that approach was being replaced by setting the winch brakes so that the warps would run out slowly in an emergency. ${ }^{78}$

The bridles of a Hearder trawl were handled over each quarter of a yacht ${ }^{79}$ and the same was tried with the paired warps of commercial otter trawls, though arrangements were soon devised for working both warps over the same side of the trawler. ${ }^{80}$ By 1899, McIntosh ${ }^{81}$ offered an account of shooting an otter trawl in the manner familiar decades later. The final step of towing from the gallows, rather than over rollers in the rail, required something stronger than Scott's frames, which only served for hoisting the otter boards clear of the sea. ${ }^{82}$ Heavy gallows of $\mathrm{H}$-section steel, bearing top-sheaves through which the warps were rove (Figure 7 ), were not patented but appeared by $1898 .{ }^{83}$

The greatest weakness with the otter trawls of 1895 lay, however, in the design of the nets themselves. The central point of Scott's innovation had been combining

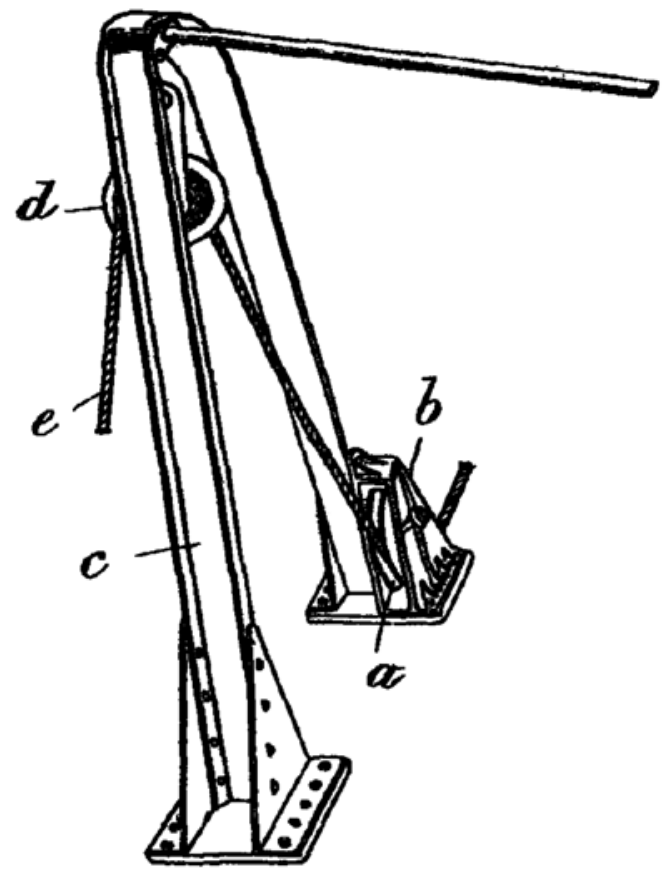

Figure 7 : Port after trawl gallows of circa 1904 [from UK patent 190420423, downloaded from http:// worldwide.espacenet.com]. a, b: patent roller fairlead, $\mathrm{d}$ : top block, e: trawl warp. The bar at the top is a stay.

77 McIntosh, "Professor McIntosh's Report," 354.

78 M'Intosh, "Remarks on trawling," 314-315.

79 Bickerdyke, 307.

80 Cunningham, 114, 116. The trawlers given otter gear in 1895 went fleeting, a practice now almost forgotten. During the 1920s and '30s, trawlers fitted for that work towed from each quarter, one warp being blocked up, as when "single-boating," while the other was taken across the stern and a chain guy hooked into one of a series of shackles in the warp [Davis, 108]. Cunningham saw the first essays in the development of that technique.

81 W.C. McIntosh, The Resources of the Sea, (London: Clay, 1899), 61.

82 M'Intosh, "Remarks on trawling," 318.

83 Henry Howard and Alexander Robb of Hull were granted UK patent 1898119780420423 for an improved lead of the warp from winch to gallows and, in their drawings, illustrated the heavy form as though it was then standard. 
otter boards with square nets. ${ }^{84}$ Yet, even his large boards could not stretch a headrope straight. Those of his trawls, like all others before and since, inevitably sagged backwards, pulling their wings together and severely distorting the shape of the net. There was too much tension down the sides, while meshes behind the centre of the headrope flapped loose. They could be pushed downwards by water flowing above them (instead of up, by water passing through) and Kyle noted the "greatest difficulty" in working an otter trawl of circa 1900 as stopping the headrope dragging on the seabed ${ }^{85}$ Instead of Scott's futile attempt to straighten a square net or Nielsen's surrender to the curvature, what was required was a trawl designed to accommodate the inevitable curve, while maintaining the trapping action of a beam trawl.

Each beam-trawl net was made from seven flat panels (Figure 8A), not counting its pockets, flapper or chaffing gear. The first, the square, ${ }^{86}$ was fastened to the headrope and thence to the beam. The net's conical taper was formed of two trapezoidal pieces, the belly and batings, laced together down their sides. The codend was likewise formed from two rectangular pieces, laced together into a tube, its end closed by the codline when fishing. The leading edge of the codend was laced to the trailing edge of the belly and batings, while the leading edge of the batings was laced to the trailing edge of the square. The ends of the footrope were shackled to the trawl heads and its bosom fastened to the middle of the leading edge of the belly. That left a space on either side, between square and footrope, from trawl head to belly. Each was filled with a tapered panel, a wing.

Such a net could be converted for otter trawling, by fitting triangular top wings ahead of the square, while lengthening the former wings (renamed lower wings) to match. That solution was reached swiftly. In Scotland, top wings were adopted "within a year after the introduction of the otter-trawl." ${ }^{87}$ Hewett's records of otterboard designs are accompanied by net plans for eight different otter trawls, all dated to $1897 .{ }^{88}$ They show both early top wings and the emergence of trapezoidal squares (Figure 8B). By 1903, well-developed top wings were sufficiently standard that Kyle illustrated them without mention of their introduction (Figure 8C). ${ }^{89}$

Nets of Kyle's time were still short, resembling beam trawls with top wings. Longer nets came later, though there is little record of that change in design. It was well advanced by the early 1920s, when Davis provided a simplified plan of a contemporary otter trawl (Figure 8D).$^{90}$ Further lengthening and refinement led to the famed Granton trawl (Figure 8E), which became the standard in Britain until the

84 Anon., "Scott v. Hamling," 124.

85 Kyle, 580.

86 Not to be confused with "square net" - meaning an entire beam-trawl net, in contradistinction to Hearder's or Nielsen's nets.

87 Fulton, 119.

88 Essex Record Office, D/F 13/9, 112-114.

89 Kyle, 573-582, plate II.

90 F.M. Davis, "An account of the fishing gear of England and Wales," Fishery Investigations Ser.II, 5:4 (March, 1923), 94. 

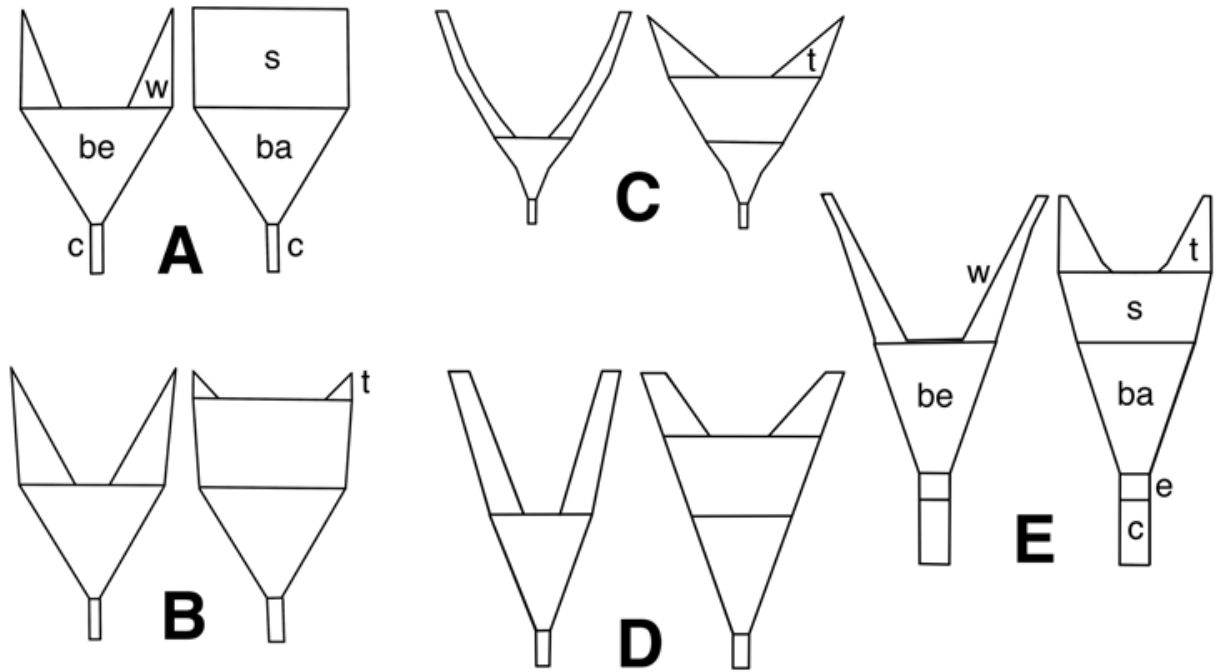

Figure 8 : Simplified net plans of various trawls, each showing underside of net on left and upper on the right, all scaled to the same width of the square. A: Beam trawl, 1897, B: Gorleston otter trawl, 1897, C: Otter trawl, 1903, D: Otter trawl, 1923, E: $78 \mathrm{ft}$ Granton trawl; ba: batings, be: belly, c: codend, e: extension, s: square, t: top wing, w: (lower) wing [prepared by author, based on: A and B: Essex Record Office, D/F 13/9, 114 and 111 respectively; C: Kyle, "Fishing nets, with special reference to the otter trawl," Journal of the Marine Biological Association, VI (1903), Plate II; D: Davis, "An account of the fishing gear of England and Wales," Fishery Investigations, Ser.II, V (1923), 94; E: Dickson, "Performance of the Granton trawl," in: Modern Fishing Gear of the World 2, (London, 1964), 522]

end of side-trawling in the 1970 s, despite its severe deficiencies. ${ }^{91}$ Unfortunately, neither the date of its introduction nor its association with Granton is clear. ${ }^{92}$

By then, Jean-Baptist Joseph Alphonse Vigneron, a French engineer, and Oscar Dahl, the armateur who initiated steam trawling out of La Rochelle, had developed practical means for handling otter boards connected to nets by sweep wires, which herded more fish into trawls. ${ }^{93}$ Meanwhile, German engineers were designing herring trawls with high headropes,${ }^{94}$ commencing the science-based evolution of trawling technology that has extended to the present.

91 The $78 \mathrm{ft}(23.8 \mathrm{~m})$ Granton trawl, the version used by the fleets of Hull and Grimsby, had several weaknesses, including a headrope height little greater than that of nineteenth century beam trawls. See W. Dickson, "Performance of the Granton trawl," in Modern Fishing Gear of the World 2, (London: Fishing News Books, 1964), 521-525.

92 Frequent claims notwithstanding, the Granton design was not a net promoted by Scott in the 1890s. It was first mentioned in the scientific literature in 1929. See F.M. Davis, "Preliminary note on experimental trawling with cod-end meshes of different sizes," Journal du Conseil 4:3 (December 1929), 287-299.

93 H. Moulinier, La Pêche industrielle de La Rochelle: Les grands chalutiers (1871-1994), (Rennes: Universitaires de Rennes, 2015), 71-74, 129-132.

94 D. Sahrhage and J. Lundbeck, A History of Fishing, (Berlin: Springer-Verlag, 1992), 116. 


\section{Fishing power of otter trawls}

Commercial otter trawls were swiftly adopted during the 1890s because they caught more than beam trawls did. Fishermen saw an increase of 33 to 50 percent overall and a doubling for roundfish. ${ }^{95}$ Walter Garstang, attempting a more formal comparison, found little difference in flatfish catches but a one-third increase in haddock and a doubling of cod (an overall 37 percent increase in catch weight, though not in its value). T. Wemyss Fulton estimated an 11 percent decline in flatfish but increases of 40 percent in haddock and 62 in cod, while the whiting (Merlangius merlangus) catch almost doubled. ${ }^{96}$ At the time, it was much less obvious why the new gear was so successful.

Some supposed that the longer headropes of otter trawls gave greater wingspread and increased headrope height. ${ }^{97}$ They did not. By 1902, netmakers thought that wingspread was two-thirds headrope length and long after, once net-measuring instruments were available, the Granton trawl proved to have a wingspread of 63 percent headrope length,$^{98}$ suggesting that the netmakers had not been far wrong. Thus, even the larger nets of 1895 had wingspreads under twenty metres, or little more than contemporary trawl beams.

The actual advantage of early otter trawls lay in the observation which induced Scott to begin his experiments: fish, especially roundfish, avoided the visual and auditory cues emitted by trawls as they trundled across the seabed.$^{99}$ The behaviours of fish around fishing gear have still not received sufficient study, though much has been learnt in recent decades ${ }^{100}$ and there is nothing now surprising in the improved catches of the otter gear of 1895. In particular, fish respond to vibrations emitted by trawl warps drawn through water under tension. While their behaviours

95 Cunningham, 116; Garstang, 50.

96 Garstang, 50-51; Fulton 122-126. There were further studies of catches per fishing hour (a measure of scientific interest), rather than the commercially relevant catch per day at sea. See: W. Garstang, "Report on the trawling investigations, 1902-3, with especial reference to the distribution of the plaice," Marine Biological Association of the United Kingdom. International Fishery Investigations. First Report, (London: HMSO, 1905), 67-197; R.M. Lee, "Comparative notes on various trawler catches in the North Sea, including some steam trawler records for 1903 and 1905," Marine Biological Association of the United Kingdom. International Fishery Investigations. Fourth Report, (London: HMSO, 1912), 291-302.

97 Anon., "Scott v. Hamling," 123; Cunningham, 116-117; McIntosh, The Resources of the Sea, $66,91-92$.

98 Dickson, 525. Fulton, 120-122, attempted direct measurements while trawling in shallow water, concluding that his wingspread was little more than half headrope length (though he thought that commercial trawls might do better). In practice, the short warps of shallow trawling prevented his otter boards from spreading fully.

99 To his credit, Cunningham, 117, recognized that reduced gear avoidance was part of the explanation for higher catches.

100 Useful reviews have been provided by: C.S. Wardle, "Fish behaviour and fishing gear," in: T.J. Pitcher, ed., The Behaviour of Teleost Fishes, (London: Croom Helm, 1986), 463-495, and P. He, ed., Behavior of Marine Fishes: Capture processes and conservation challenges, (Ames: Wiley-Blackwell, 2010). 
are hard to study in midwater, astern of a trawler and ahead of her trawl, modern acoustic instruments have revealed strong reactions by cod. They dive obliquely, to avoid the perceived threat, until confined between warp, seabed and on-coming trawl, when they attempt to escape laterally. ${ }^{101}$ A trawl towed on a single warp thus herds roundfish away, whereas paired warps encourage the fish between them to concentrate in front of the net. Hence, the success of Scott's promotion lay in his use of paired warps - which were barely mentioned at the time.

Since the advantages of otter trawls depend on fish behaviour, rather than net geometry, they differ among species. Trawling had grown by exploiting resources invulnerable to baited hooks, while cod were left to line fishermen. Otter trawls fished on paired warps changed that, opening the way to massive cod fisheries, with hake and pollock trawling following.

\section{Worldwide Adoption}

Pérotin was unquestionably correct when he declared, in 1911, "le chalutier à vapeur est le roi de la pêche" ${ }^{102}$ but it was more. The Edwardian steam otter trawler was a superlative machine for gathering food - the ultimate application of steam and steel to that purpose. It had no equal until the self-propelled combine harvester became practical during the 1930s. What the combine was to cultivated grains on land, the steam trawler was to wild animal protein from the sea. Unlike their agricultural analogues, however, trawlers exploit naturally limited production systems under common-property regimes and their efficiency made over-exploitation of major, open-sea resources economically viable - a challenge not adequately addressed until too late.

The technology was widely and swiftly applied. By 1913, there were 1,683 steam otter trawlers in the United Kingdom, ${ }^{103}$ near half as many in Germany, 200 in France and almost 100 in the Netherlands, while Belgium, Spain and Portugal each operated a dozen or more. ${ }^{104}$ Steam trawling was promoted around the British Empire, small fisheries emerging from New Zealand to Nova Scotia. ${ }^{105}$ There was early interest in Japan and a fishery in New England from $1905 .{ }^{106}$ By then,

101 N.O. Handegard and D. Tjøstheim, "When fish meet a trawling vessel: examining the behaviour of gadoids using a free-floating buoy and acoustic split-beam tracking," Canadian Journal of Fisheries and Aquatic Sciences 62:10 (October 2005), 2409-2422.

102 Pérotin, 3.

103 Anon., "The history of trawling," 57.

104 Pérotin, 69-74

105 D. Johnson, Hooked: The story of the New Zealand fishing industry, (Christchurch: Hazard Press, 2004); A.L.L. Jacobsen, "The NSW Steam Trawl Fishery on the South-East Continental Shelf of Australia, 1915-1961," in: J. Christensen and M. Tull, eds., Historical Perspectives of Fisheries Exploitation in the Indo-Pacific, (Dordrecht: Springer, 2014), 191-210; B.A. Balcom, "Technology rejected: steam trawlers and Nova Scotia, 1897-1933," in: J.E. Candow and C. Corbin, eds., How Deep is the Ocean? Historical essays on Canada's Atlantic Fishery, (Sydney: University College of Cape Breton Press, 1997), 185-194.

106 A.W. German, "Otter trawling comes to America: The Bay State Fishing Company, 19051938," American Neptune 44:2, (Spring 1984), 114-131. 
internal-combustion motors were making smaller-scale otter trawling viable. That led, in time and in combination with much larger factory trawlers, to the general, worldwide adoption of otter gear.

\section{Conclusions}

In summary, far from the otter trawl being introduced by Scott in the mid-1890s, it had a gradual development over a half-century, beginning around 1860. The evolution of nets suited to otter gear extended into the 1920s, by which time the technological development of subsequent decades had begun. Nor was one man alone responsible. Musgrave, Hearder, Nielsen, Alward and others played important roles. Scott did develop the otter-board bracket but his critical contributions lay in promoting the new gear and (almost inadvertently) in adopting paired warps.

The gradual development of otter trawling casts doubt on some recent research in environmental history. There has been an attempt to reconstruct an otter trawl of 1897 for comparative fishing on early survey stations, predicated on an assumption that net designs stabilized swiftly after Scott's patent, changing little thereafter until Vigneron and Dahl's advance. ${ }^{107}$ Others have applied the century-old comparisons of beam- and otter-trawl catch rates, presented by Garstang and Fulton, to better quantify long-term resource declines. ${ }^{108}$ The original studies involved multiple uncertainties $^{109}$ which always made the modern applications doubtful. To those, the present study has added an appreciation of the prolonged increase in otter-trawl efficiency into the 1920s, casting doubt on the relevance of comparisons made around 1900 - and on any use of historical scientific estimates without historical understanding.

107 J.C. Currie, K.J. Sink, C.G. Attwood, L.J. Atkinson and G.H. Engelhard, "Reconstructing the past: design and function of Granton otter trawl gear at the turn of the twentieth century, as used in South Africa's first trawl surveys (1897 - 1904)," Maritime Studies 18:1 (April 2019), 1-16.

108 e.g. G.H. Engelhard, "One hundred and twenty years of change in fishing power of English North Sea trawlers," in: A. Payne, J. Cotter and T. Potter, eds. Advances in Fisheries Science: 50 years on from Beverton and Holt (Oxford: Blackwell, 2008) , 1-25; R.H. Thurstan, S. Brockington and C.M. Roberts, "The effects of 118 years of industrial fishing on UK bottom trawl fisheries," Nature Communications I:15, 2010, 6 p.

109 J.T. Jenkins The Sea Fisheries (London: Constable, 1920), 27. 